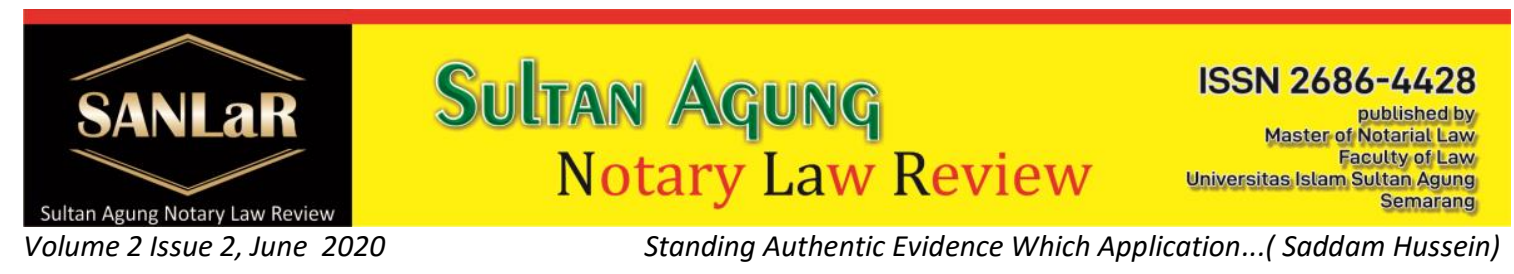

\title{
Standing Authentic Evidence Which Application Made By Notary-PPAT Of Uitvoerbaar Bij Voorraad (Ruling That Can Run Over First)
}

\author{
Saddam Hussein ${ }^{*}$ and Jawade Hafidz ${ }^{* *}$ ) \\ *) Student Master of Notary Program, Faculty of Law, Sultan Agung Islamic University, \\ Semarang, email: advokat_saddam@yahoo.com \\ ${ }^{* *}$ Lecturer, Faculty of Law, Sultan Agung Islamic University, Semarang
}

Abstract. This study aims to determine the extent of the Status Evidence Authentic Notary or PPAT made towards the implementation of Voerbaar Uit Voorraad Bij (The decision to run first) in the District Court of Class IA Kendari. This study uses normative juridical approach, where data is collected through the study of literature materials and interviews and then analyzed by qualitative descriptive method is an argument of a logical and systematic law in accordance with the formulation of the problem has been formulated.

From the results of the research it is concluded that from the point of view of the Law of Evidence in the world of Justice in Indonesia that the Position of Authentic Evidence made by a Notary or PPAT is the same / equivalent to other Authentic Evidence made by other authorized officials such as BPN, Camat, Bailiff, etc., as well as Decisions that can be implemented in advance (uitvoerbaar bij voorraad) and decisions that have permanent strength still experience obstacles in their implementation. These obstacles are caused by both juridical and non-juridical factors. Decisions that can be implemented first (uitvoerbaar bij voorraad) are still very rare, practiced in district courts, especially the Klas IA Kendari district court, that based on our research results, data is obtained that within a period of 4 years, from January 2016 to December 2019 The Kendari District Court has only 1 (one) decision regarding the uitvoerbaar bij voorraad. The obstacles experienced by judges in the District Court, especially the Kendari District Court, are due to the tight supervision of the High Court and the Supreme Court. Because in order to carry out a decision that can be implemented in advance (uitvoerbaar bij voorraad), it must obtain approval from the High Court, and even the High Court before allowing the implementation of the decision or execution, sometimes asking for consideration from the Supreme Court. This is the cause of the Judges' reluctance to issue a verdict that can be implemented first (uitvoerbaar bij voorraad).

Keywords: Authentic Evidence; Notarial Deed; Bij Voerbaar Uit Voorraad.

\section{Introduction}

Guaranteeing the rule of law, order and legal protection that core truth and justice. Charges against legal protection in the development of public life one of which is reflected in the traffic rules of evidence, the evidence to determine clearly the rights and obligations of a person as a subject of law in society. In the Book of the Law Indonesian Civil Code Article 1866, known on the evidence which consists of: written 
evidence, evidence by witnesses, suspicion-suspicion, recognition, and vows. Regarding the written evidence included therein is an authentic act which is an act made in the form required by the Act, made by or before the competent public authority to make the deed, the place where the deed was made (Article 1868 of the Civil Code). A public official in question is a notary, judge, bailiff in a court of law, civil servants and officials note auction. To make an authentic deed a Notary must follow the rules set out in legislation. ${ }^{1}$

In the case of a notarial deed entitled to make authentic act is the Notary, as a notary has been appointed as the sole public officials entitled to make all the authentic act, unless the legislation another set. Authentic deeds as the strongest evidence and filled an important role in any legal relations in society. Perfect as evidence the intention is the truth revealed in deed it does not need to be proven with the help of other evidence. $^{2}$

Settlement of civil disputes through the courts originated from case registration until the ruling by the judge, but the judge's decision just yet restore the rights of a party because the judge's ruling was limited to stating the loser and winners and contains a command to the losing to implement the decision. The rights of the injured party will be restored if the judge's ruling has been implemented, either voluntarily by the losing and if the losing party does not want to implement the court ruling voluntarily, then the party who won the case can request the implementation of decisions by force or execution. According Sudikno Mertokusumo (2002: 239) states: "A court decision means nothing if it can not be implemented. Therefore, the decision of the judge has the power executorial that is the power to implement what is laid down in the decision forcibly by the state apparatus ".3

But how disappointed after being declared the winner turns awaited verdict also can not be executed. Because it nevertheless delayed enforcement of the award or execution or for a cause that the judge's decision can not be implemented or executed at all can lead to disappointment and even distrust, especially the winning side against the judiciary in the sense of distrust of the legal actors involved in it.

Various spotlight could arise, ranging from issues of injustice judges, bribery, discrimination until the issue of lack of professional judges included the highlighted. In particular, we in Indonesia must be acknowledged that since the end of 1998 ago as the beginning reformation and at the end of the New Order regime, the public spotlight to courts is becoming more prominent, and the result is the public confidence in the judiciary has been at the lowest levels. Even Achmad Ali (2004: 19) states: In social level of confidence of citizens of Indonesia to the legal order, including the order of the court already in a stage " bad trust society ". The main cause further destruction

\footnotetext{
1 Arifin, Zaenal., and Witasari, Aryani. "Notary Role In Making The Establishment Of The Deed Of Business Cooperation In The Rembang District". in Jurnal Akta Volume 6 Issue 3, September 2019. p. 574. , url http://jurnal.unissula.ac.id/index.php/akta/article/view/5102

${ }^{2}$ https://notarisarief.wordpress.com/2011/04/21/pembuktian-akta-otentik/.html accessed on September 23, 2019 at 3:20 pm

${ }^{3}$ Mertokusumo, Sudikno. (2002) Hukum Acara Perdata Indonesia. Yogyakarta : Liberty Yogyakarta. p. 239
} 
of public confidence is that the government is now in law enforcement. In public optimism to better law enforcement and the rise of the era that is consistent with Suharto, now back turned into pessimism. ${ }^{4}$

Regarding the implementation of the decision to be implemented first (Bij Voerbaar Uit Voorraad), if the note is very rare and endangered practiced in a decision in the courts, especially in the District Court of Kendari. Court judgment which can be carried out first (Bij Voerbaar Uit Voorraad), as stipulated in Article 191 paragraph (1) R.Bg, states "That the District Court may order the execution while the decision even though there is opposition or appeal if there is evidence of an authentic or there letter written by hand according to the applicable provisions have the force of proof, or having previously been no decisions have the force of law is certain, Likewise if their demands were granted provisional, and involves a dispute about the rights.

The research I have done in the District Court of Kendari, concerns regarding the Status Evidence of Authentic created Notary or PPAT to the adoption of a decision can be carried out first (Uit Voerbaar Bij Voorraad), I get the data, that the implementation or application of Article 191 paragraph (1) RBG , In the district court Kendari, about decisions that can be implemented earlier (voerbaar uit bij voorraad), there is only one verdict for four years, the data is addressing how the lack of application of Article 191 paragraph (1) RBG.

The verdict can be carried out first (Uit Voerbaar Bij Voorraad), from 2016, 2017, 2018 and 2019, or for 4 years, it turns out decisions concerning Decision Executable Over the past (Uit Voerbaar Bij Voorraad) only amounted to 1 (one) decision. The verdict is the case arise of the object of dispute is the issue of land. The decision namely: Kendari District Court's Decision No.30 / PDT.G / 2017 / PN.KDI, ${ }^{5}$ With the object of the dispute is the land issue. While the evidence presented is authentic evidence, namely Certificate of Property Rights. It meets the requirements as stipulated in Article 191 paragraph (1) RBG. For a workable decision handed down earlier (Bij Voerbaar Uit Voorraad).

\section{Method approach}

This approach is normative juridical study, the research study and guided by various legislations and regulations. Primary data in this study was obtained through the method of interviews with relevant parties (informants) the party is a Class 1A District Court of Kendari. Secondary data were obtained from official documents, books related to the object of study, research and legislation.

\section{Results and Discussion}

3.1. Authentic Evidence Notch Which Created the Notary-PPAT Against Application voerbaar uit bij voorraad (The verdict can be carried out first). In the District Court of Kendari.

\footnotetext{
${ }^{4}$ Ali, Achmad. (2004). Sosiologi Hukum, Kajian Empiris Terhadap Pengadilan. Jakarta: IBLAM. p. 19

${ }^{5}$ http://sipp.pn-kendari.go.id
} 
Proof is a process, method, action to prove or attempt to show the truth in court. Authentic act has the strength of evidence that was perfect for the parties, their heirs and those who get the rights for it. Thus the authentic act can only be overturned by opponents of evidence. Judges may only cancel the notarial deed if requested cancellation by the parties to the dispute, based on solid evidence and perfectly conveyed the applicant to judge, without any request for cancellation of the deed judges are not necessarily able to cancel the authentic act is the object of the dispute in court , ${ }^{6}$ Based on the description of Kendari District Court Judge, Mr. TAHIR, SH. Authentic Evidence on Position created Notary or PPAT against Uit Voorraad Bij voerbaar (court decision to deploy first) in accordance with Article 191 paragraph (1) RBG.

According to Mr. TAHIR, SH. The authentic proof made Notary or PPAT has a value of perfect proofing and binding strength (wolledig en bindende bewij kracht). If the lawsuit filed supported by evidence of an authentic deed and the deed turns truth can not be paralyzed defendant with evidence already fulfilled the requirements opponent's decision to grant the request voerbar uit bij voorrad. However, in practice in the District Court of Kendari though a lawsuit has been supported by the evidence has perfect evidentiary value and binding force, kept open the possibility of the decision overturned on appeal or cassation so as to better reject the verdict uit bij voerbar voorrad. In connection with the decision of voerbaar uit bij voorraad (decision to be implemented first), ${ }^{7}$ (Vide. SEMA 3 of 2000 Figures 4a ("The lawsuit is based on evidence the letter or a handwritten letter (handschrift) are not denied the truth about the contents and the signature, which according to the legislation does not have the force of evidence") ${ }^{8}$.

As noted at the beginning of the discussion that the process of settlement of civil disputes in court will end up with the ruling judge. But the judge's decision merely establishes the parties who lost and who won, not to recover the losses suffered by a party. New losses will be restored if the court's decision have been implemented or executed. Thus the implementation of court rulings is the most essential stage of the whole process through. But not infrequently happens that the court ruling, both of which already have permanent legal force as well as the decision to run first, and still can not be executed with a wide variety of causes, both legal factors as well as nonlegal factors.

Surely it is a legal issue faced by seeking justice until now, because it will lead to justice and legal certainty factors not be achieved. As stipulated in the "Act 8. 2004. On Judicial Power who asserts that the: "Judicial Power is an independent state authority to administer justice to uphold law and justice based on Pancasila, for the implementation of the State of Law of the Republic of Indonesia." ${ }^{19}$

\footnotetext{
6 https://notarisarief.wordpress.com/2011/04/21/pembuktian-akta-otentik/.html accessed on September 23, 2019 at 3:20 pm

${ }^{7}$ Interview with TAHIR, SH as Class $1 \mathrm{~A}$ District Court Judge Kendari

${ }^{8}$ Supreme Court Circular Letter No. 03 of 2000, item 4 a.

${ }^{9}$ Act 8. 2004. On Judicial Power
} 
The Act included several principles of justice. Among them is what is referred to in Article 4 (2), Act No. 8 of 2004 on Judicial Power; which asserts that "Justice is done with Simple, Fast and Lightweight costs." This principle is included in the scope of procedural law. Sufficient and appropriate knowledge regarding procedural law in the courts is a major factor realization of the principle in question. One embodiment of the principle such implied by Article 191 paragraph (1) RBG, which is known as an authority Decision which can be first (voerbaar uit bij voorraad). If the specified requirements can be met. It turns out in practice, still very rarely carried out by the District Court in particular District Court of Kendari. It can be seen from the fact that there are, especially in the District Court of Kendari, based on research results, we obtain the data which the samples we took was the verdict began 2016 and 2019 during the 4 (four) years.

The District Court's decision are as follows: Decision No.30 / Pdt.G / 2017 / PN.Kdi, That is the case between H. HERRY ASIKU, SE. / Plaintiff - against - 1. Njo. Winyoto Gunawan, 2. Mbatong / Defendants. In this case the District Court panel Kendari, in the verdict, had granted the request (Uitvoerbaar Bij Vorraad) Plaintiff: - a decision based on the evidence of the authentic, which in this case is the Certificate of Property Rights, issued by the competent authorities; Consideration of the above law judges, clearly basing his judgment on any of the requirements stipulated in Article 191 paragraph (1) RBG. Namely the existence of authentic evidence in decisions that can be implemented earlier (voerbaar uit bij voorraad).

Although not yet have the force of fixed / definite, because the defendant appealed, but the District Court of Kendari been able to carry out the execution of the object of the dispute, in accordance with Article 191 paragraph (1) RBG. An appeal or an appeal by the defendant does not impede the implementation of the execution. However, by virtue of the Supreme Court Circular, if the decision of the district court that verdict declared enforceable in advance (Uit Voerbaar Bij Voorraad), if it will be implemented execution must obtain permission from the Chairman of the High Court, in addition to the plaintiff as of the petitioner should save money guarantee a value of the object to be executed. This is one of the obstacles faced by the plaintiffs, in applying the enforcement (execution), although the plaintiffs know that his case can already be implemented or in execution, but that the plaintiff objected and could not afford to pay / save bail accordance with the provisions required by the District Court by the Supreme Court Circular. If reality as such, the agency that regulates the implementation of the District Court decision can be carried out first (voerbaar uit bij voorraad) as stipulated in Article 191 paragraph (1) RBG. It becomes useless and ineffective, because even though the District Court had ruled that can be implemented earlier (voerbaa uit bij voorraad), but implementation is very difficult and complicated, such as to make the implementation of the court ruling the country,

With these difficulties lead to the adoption uit bij voorraad voerbaar becomes useless and ineffective, and the ideals of the things that are fast, simple and low cost can not be achieved. This is caused from the doubts of the Supreme Court, in applying institution voerbaar uit bij voorraad. 


\subsection{Resistance and Solutions Faced state court Kendari In Voerbaar Bij Uit Voorraad Application (Decision Executable Over the past)}

Implementation of the Decision Over the past Executable (Uit Voorraad Voerbaar Bij) in court, especially in the District Court of Kendari encounter obstacles, this is due to:

a. Precautionary judges in applying Uit Voorraad Voerbaar Bij (decision to run first) is.

b. that the district court judge was impressed kendari not want to bother, because in implementing Voerbaar Bij Uit Voorraad verdict or decision to run first, had to get permission or approval of the High Court.

c. The existence of multiple Circular and Instruction Court which contains restrictions on the implementation of decisions that can be executed first.

Circular and the instructions of the Supreme Court is, among others:

- Supreme Court Circular Letter No.03 of $2000^{10}$,

- Instructions Supreme Court 348 / K / 5216 / M 195811,

In the Circular and the instructions of the Supreme Court essentially asked the Court of the State that are not easily drop Decision Over the past Executable (Uit Voorraad Voerbaar Bij) and will execute the decision if the District Court must obtain permission and approval from the High Court.

Based on the description of Kendari District Court Judge, Mr. TAHIR, SH. About the lack of penetrapan Uit Voorraad Bij voerbaar (court decision to deploy first) in accordance with Article 191 paragraph (1) RBG. As well as obstacles and solutions faced by the District Court of Kendari in applying uit bij voorraad voerbaar it.

According to Mr. TAHIR, SH. That the lack of implementation Uit Voerbaar Bij Voorraad (verdict which can be carried out first) as stipulated in Article 191 paragraph (1) RBG such, is concerned the prudence of the panel of judges in decisions that can be implemented first, because the decision of some sort it has consequences that are very risky because it can cause the law in the future, for example for example if the decision turned out to be the level of appeal or cassation, the decision is annulled, there arises a legal issue, because the decision of the district court have been executed, and if this problem occurs, then very difficult to restore the original condition.

So the complexity of implementing the decision uit bij voorraad voerbaar it. Not only there, if after the approval of the High Court, it is still necessary that the other requirements, Plaintiff Parties are still obliged to keep guarantee to the court by the amount equivalent to the object of the goods to be executed. Of course, all of these requirements in order to minimize the risk of legal problems in the future, if an error occurs to restore the situation to normal. To the Supreme Court has issued several Circular which basically contains additional requirements that must be met by the district court passed a decision if you want voerbaar uit bij voorraad (decision to be implemented first), though have met the elements contained in article 191 paragraph (1) RBG. Judges are still advised to be more careful.

\footnotetext{
${ }^{10}$ Circular of the Supreme Court of the Republic of Indonesia, No.03 of 2000

${ }^{11}$ Instructions Supreme Court of Indonesia, 348 / K / 5216 / M 1958
} 
That the opinion of Mr. TAHIR, SH regarding Solutions voerbar uit bij voorrad application is Judges should really run Setup at SEMA No. 3 of 2000 which was sufficiently clear and precise, in order to be guided. Thus the opinion of Mr. TAHIR, SH. Judge of the District Court of Kendari, about barriers and solutions encountered in implementing voerbaar uit bij voorraad in the District Court of Kendari.

So barriers and solutions so the application Uitvoerbaar bij voorraad or Decision Executable Over the past by the district court. Actually, the difficulties and obstacles are not the reason for the District Court of Kendari in applying Uit Voorraad Bij voerbaar such as mandated by Article 191 paragraph (1) RBG. Because if properly internalized what it is the principle of justice as stipulated in Act 8 of 2004 on Basic Provisions on Judicial Power, which affirms the principle of judicial Fast, Simple and Cost of Light. So when the district court judge actually live it, then the application Uitvoerbaar Voorraad Bij is very important and a way and an opportunity to realize the principle of the principles of fast, simple and low cost trial as mandated by Law No.8 of 2004.

\section{Closing}

\subsection{Conclusion}

From the research we've done in the District Court of Kendari, That notch authentic proof made Notary or PPAT has a value of perfect proofing and binding strength (wolledig en bindende bewij kracht). In connection with the decision of voerbaar uit bij voorraad (decision to be implemented first), there was no difference in the strength of evidence notarial deed with another deed, even under the letter of the hand, to the extent not denied by the opponent (Vide. SEMA 3 of 2000 Figures 4a). However, in practice in the District Court of Kendari though a lawsuit has been supported by the evidence has perfect evidentiary value and binding force, kept open the possibility of the decision overturned on appeal or cassation so as to better reject the verdict uit bij voerbar voorrad. That for four years, Kendari District Court's decision regarding the application of Uitvoerbaar bij voorraad or decisions that can be implemented in advance only for the amount of 1 (one) decision. The lack of implementation of Uit Voerbaar Bij Voorraad in the District Court of Kendari, mainly because of the constraints faced by the District Court of Kendari is due prudence of judges and the lack of appreciation of the district court judge kendari about the importance of the implementation of the agency in creating the principle of justice quickly, simple and inexpensive. Beside that the obstacle is the district court judge kendari not want to be bothered or bother, because if the verdict Uitvoerbaar bij voorraad (breaking can be carried out first) Kendari District Court judges must ask permission and approval from the High Court. The next obstacle is the attitude of the Supreme Court, as outlined in the Circular Letter and Instruction, which in essence that the Supreme Court gave the restrictions in applying the Voorraad Bij Uitvoerbaar institutions. All of this is what led to the adoption agency Voerbaar Uit Voorraad Bij is not received full attention by the District Court of Kendari. which in essence that the Supreme Court gave the restrictions in applying the Voorraad Bij Uitvoerbaar institutions. All of this is what led to the adoption agency Voerbaar Uit Voorraad Bij is not received full attention by the 
District Court of Kendari. which in essence that the Supreme Court gave the restrictions in applying the Voorraad Bij Uitvoerbaar institutions. All of this is what led to the adoption agency Voerbaar Uit Voorraad Bij is not received full attention by the District Court of Kendari.

\subsection{Suggestion}

Notary and PPAT that still has the name Good and High Confidence in the community and other law enforcement agencies, it is expected to order whole Notary and PPAT in Indonesia, while maintaining the good name and the trust to the public and other law enforcement according to the rules applicable legislation. It is expected that the district court judge would really appreciate and seek to apply and implement Voorraad Bij maximum Uitvoerbaar institutions, of course, if the terms of verification as provided for in Article 191 paragraph (1) RBG and SEMA No. 3 in 2000 have been met. It is expected that the Supreme Court and the High Court gives motivation or even provide oversight and accost court if not pay attention to the application of Voerbaar Bij Uit Voorraad institution, if the proof is in compliance as specified in Article 191 paragraph (1) RBG. The.

\section{References}

\section{Journal and Internet}

[1] Arifin, Zaenal., and Witasari, Aryani. "Notary Role In Making The Establishment Of The Deed Of Business Cooperation In The Rembang District". in Jurnal Akta Volume 6 Issue 3 3 September $2019 . \quad$ url http://jurnal.unissula.ac.id/index.php/akta/article/view/5102

[2] http://sipp.pn-kendari.go.id accessed on 20 September 2019 At 3:52 pm

[3] https://notarisarief.wordpress.com/2011/04/21/pembuktian-aktaotentik/.html accessed on September 23, 2019 at 3:20 pm

\section{Books}

[1] Ali, Achmad. (2004) Sosiologi Hukum, Kajian Empiris Terhadap Pengadilan. Jakarta: BP IBLAM

[2] Mertokusumo, Sudikno. (2002). Hukum Acara Perdata Indonesia. Yogyakarta: Liberty

[3] Robert K. Yin, 2008, Studi Kasus, Desain \& Metode, Issue 1, CET 12, , Jakarta: King Grafindo Persada

\section{Regulation Legislation}

[1] Constitution of the Republic of Indonesia of 1945.

[2] The Civil Code / BW (Burgerlijke wetboek).

[3] The Code of Civil law

[4] Civil Procedure Article 191 paragraph (1) RBG

[5] Circular of the Supreme Court of the Republic of Indonesia, No.03 of 2000

[6] Instructions Supreme Court of Indonesia, 348 / K / 5216 / M 1958 